\title{
O tabu do incesto e a bioantropologia
}

\author{
— José Francisco Carminatti Wenceslau \\ André Strauss
}

resumo $\mathrm{O}$ debate acerca do tabu do incesto tem sido amplamente discutido até mesmo antes da fundação da antropologia como disciplina. Porém, foi nessa área do conhecimento que o tema adquiriu atenção acentuada, em especial após a publicação do renomado trabalho de Claude Lévi-Strauss, As estruturas elementares do parentesco, em 1949. Grande parte das escolas de ciências sociais brasileiras toma o assunto como encerrado por esse autor, contudo, isso está longe de ser verdade. Neste artigo procuramos reacender o debate com o estruturalismo lévi-straussiano e a sua principal teoria a respeito da proibição do incesto - a teoria da aliança - através do levantamento de diversos estudos que de algum modo dialoguem com a obra desse autor. Deste modo, com especial auxílio dos trabalhos de fronteira entre a biologia e a antropologia - que muitas vezes náo chegam ao contato dos cientistas sociais - desejamos reavivar essa reflexão no circulo acadêmico brasileiro.

palavras-chaves Lévi-Strauss. Endocruzamento. Etologia. Primatologia. Endogamia

A proibição do incesto é um dos temas clássicos da antropologia. Nos cursos de ciências sociais brasileiros esse tema é apresentado aos alunos dentro do contexto de uma disciplina na qual se ensina o pensamento de Claude Lévi-Strauss. Como mostraremos neste trabalho, é no ensino da clássica teoria lévi-straussiana que alguns paradigmas biofóbicos são transmitidos. Isso resulta do fato de muitos membros das ciências sociais não se importarem em estabelecer qualquer tipo de contato com a produção científica das áreas biológicas.

Isso é consequência, em grande parte, do repúdio à antropologia evolucionista da virada do século XVIII para o XIX e aos conceitos pseudocientíficos e eugenistas a ela associados. De fato, essa abordagem já foi superada, sendo hoje substituída por escolas que conseguem proporcionar um diálogo mais fluente e livre de preconceitos entre a biologia e a antropologia. Porém, como essas novas escolas possuem raízes na América do Norte, seu acesso pelos cursos de antropologia brasileiros encontra-se reduzido, dada a ascendência nitidamente europeia das ciências sociais no Brasil. Isso, infelizmente, leva a um insulamento acadêmico e consequente afastamento de qualquer possibilidade de uma abordagem interdisciplinar na produção científica do país. Para a questão da proibição do incesto, a situação não é diferente, acarretando, como mostraremos nesse texto, na introjeção de inúmeros conceitos anacrônicos e incorretos no arcabouço teórico dos cientistas sociais em formação.

A seguir apresentamos uma série de informações recentes sobre temas fundamentais para a discussão da proibição do incesto. $\mathrm{O}$ norte de tal levantamento foi dado pela obra clássica em que Lévi-Strauss trata da questão: As estruturas elementares do parentesco, de 1949. Especial atenção foi dedicada aos capítulos em que o autor faz referência a temas de fronteira entre antropologia e biologia. Não se trata, em absoluto, de qualquer tentativa de discutir 
I 4 | José Francisco Carminatti Wenceslau e André Strauss

ou atualizar a sua obra no que concerne seu tema central: a teoria da aliança. Náo se trata, tampouco, de defender essa ou aquela teoria. O que se pretende dentre outras coisas é, ao confrontar alguns trechos da obra do autor francês com as informaçóes disponíveis na literatura, mostrar aos leitores que a discussão sobre o tabu do incesto permaneceu longe de se estagnar durante esses mais de 60 anos desde a publicação de sua tese. Ademais, ao expor algumas teorias de fundamentação biológica esperamos explicitar a ausência de qualquer elemento nelas que possam ser vinculados a perspectivas eugenistas, racistas, defensoras do status quo, etc.

Antes de começarmos de fato o debate deste artigo, faz-se válida uma introdução histórica a fim de situar os leitores a respeito das principais frentes teóricas que antes de Lévi-Strauss já tratavam de discutir o incesto. Entre os Sofistas, na Grécia antiga, costumava-se pregar a antítese entre physys e nomos, ou "natureza" e "convenção". Na medida em que a primeira rege os instintos do homem, sua porção individualista e competitiva, a segunda faz-se necessária para inibir tais inclinaçóes e manter a ordem social nos grupos humanos. Nesse contexto, o incesto era visto como uma prática naturalmente aversiva. Portanto, qualquer norma social que visasse repudiá-lo se tornaria dispensável. Tentando superar esse contraste, a tradição socrática se debruçou sobre a discussão da "lei natural", defendendo que a convenção nem sempre se opóe à natureza, podendo a primeira ser formulada com base na segunda. Assim sendo, o tabu do incesto passou a ser visto como uma lei regida pelos deuses, de modo que uma propensão natural humana era reforçada por penalidades divinas, por exemplo a produção de uma prole imperfeita para aqueles que consumassem o incesto (Arnhart, 2005). Essa ideia, como veremos a seguir, foi desenvolvida de maneira mais completa por Tomás de Aquino durante a Idade Média.

Para Aquino, de herança aristotélica, uma lei natural (lex naturalis) também era o reflexo da vontade de Deus, mas operava pela própria razão humana, assim como por algum instinto que nos levasse a agir sobre ela, afeição ou impulso emocional por exemplo. Por essa ótica, o casamento seria uma lei natural, já que, para ele, o matrimônio supriria duas inclinaçóes humanas: a tendência natural para a união sexual e os cuidados fraternos. Aquino fornece várias razóes pelas quais casamentos incestuosos contrariam tal lex naturalis, três delas talvez sejam as mais relevantes para este trabalho. Primeiro, além dos humanos, também em outros animais se observa um repúdio instintivo a relaçóes dessa natureza. Segundo, o reconhecimento de que unióes entre parentes próximos resultam em anormalidades físicas para a prole. E por último, o incesto desencorajaria a formação de alianças entre grupos através do casamento entre membros de famílias diferentes (cf. id., ibidem).

Essa tradição tomística e aristotélica passou a ser motivo de grande discussão durante o século XVIII. A seu favor, Francis Hutcheson, defendia que os seres humanos possuíam o instinto de animais sociais, essa sociabilidade natural favoreceria o compartilhamento de leis morais e a expressão de tais valores por todos os membros da sociedade (cf. id., ibidem). Como aluno de Hutcheson, Adam Smith também pregava conceitos semelhantes aos de Aquino. Para ele, o incesto também era avesso à natureza humana e sua prática era algo que contrariava os valores morais universais (Smith, 1976). Já Immanuel Kant, sob o dualismo hobbesiano entre instinto animal e razão humana (que resgata o contraste anteriormente feito pelos 
sofistas), ao formular o conceito de cultura, define-a como um instrumento humano responsável pela transcendência de seus instintos naturais, alcançando a razão e estabelecendo assim uma ordem social (Kant, 1983). Por essa perspectiva, o tabu do incesto volta a ser visto como uma convenção cultural.

Já no século XIX, Charles Darwin em The Descent of Man (1871), embora concordasse com Kant ao dizer que a posse de consciência e senso moral era a principal característica que diferenciava o homem dos outros animais, julgava que isso poderia ser estudado exclusivamente por uma lógica biológico-evolutiva, nesse sentido se aproximando do naturalismo smithiano. Essa ideia foi mais bem lapidada por Edward Westermarck algumas décadas mais tarde, retomando o conceito da lei natural para compreender a natureza humana. Debruçando-se sobre o tabu do incesto, Westermarck, assim como todos os outros pensadores de tradição socrática antes dele, não o vê como resultado puramente de educação ou convenção social. Baseando-se na evidência de que alguns animais selvagens também tinham a propensão de evitar o endocruzamento (fato confirmado por estudos etológicos posteriores, como veremos mais adiante), Westermarck via a aversão ao incesto como algo natural, anterior à estruturação dos valores sociais humanos. Como essa aversão é plenamente compartilhada, ela torna-se alvo de uma desaprovação moral e, portanto, se submete a leis proibitivas: vira tabu.

De maneira sucinta, a teoria westermarckiana para explicar o tabu do incesto pode ser descrita sob três hipóteses: $1^{\circ}$ ) a "hipótese da aversão" diz que uma aversão inata à relaçâo sexual é desenvolvida entre pessoas que conviveram muito próximas nos primeiros anos da infância (aversão essa também conhecida como efeito Westermarck). 20) a "hipótese da adapta- ção" propóe que essa aversão é uma adaptação evolutiva, um comportamento fixado por seleção natural desfavorecendo o endocruzamento e, portanto, as suas consequências deletérias. 3o) a "hipótese da expressão" afirma que a aversão leva a desaprovação moral e a costumes e leis proibitivas ou, pelas próprias palavras de Westermarck:

Pessoas que viveram juntas desde a infância são geralmente parentes próximos. Portanto sua aversão a relaçóes sexuais um com o outro manifesta-se em hábito e lei como uma proibição ao intercurso sexual entre parentes próximos (Westermarck, 1922, p. 193, tradução nossa).

Contemporâneo a Westermarck, Sigmund Freud rejeitava suas teorias. Freud era um hobbesiano convicto e por isso acreditava que os valores morais surgem exclusivamente para suprimir os instintos individualistas e agressivos humanos. O tabu do incesto, portanto, seria o exemplo primordial dessa negação cultural de uma natureza animal inata ao homem. Freud então propõe que a repressão desses impulsos incestuosos levaria a uma neurose própria a todos os seres humanos, ao táo conhecido complexo de Édipo (Freud, [1913] 1974). Desse modo, no início do século XX, mais uma vez o debate entre teoria socrática da lex naturalis e a dicotomia physys x nomos dos sofistas é reacendido, a primeira sendo defendida por Westermarck e a segunda por Freud.

Esse debate, no contexto de muitas escolas antropológicas contemporâneas (como é o caso das brasileiras), é tido como resolvido por Lévi-Strauss. Apropriando-se da dicotomia sofista logo no começo de As Estruturas Elementares do Parentesco, o autor propóe que um dos grandes desafios da antropologia está em saber qual a 
natureza (biológica ou cultural) da origem dos diferentes comportamentos humanos. Para ele, tudo que é universal no ser humano está ligado à sua biologia e tudo que é normativo, à sua sociologia. Nesse ponto chega-se à questão do incesto. $\mathrm{O}$ tabu quanto a essa prática varia muito de sociedade para sociedade, estando ligado a diferentes normas em cada uma delas, porém, é o único costume que pode ser encontrado, sem exceção, em todas, ressaltando o seu caráter universal. É essa observação que leva Lévi-Strauss a fazer o seu questionamento: qual é então a origem do tabu do incesto, natural ou social?

Para ele não há dúvidas: a resposta está na aliança, o tabu do incesto é resultado mais de uma convenção social do que de uma desaprovação moral, ao contrário do que postulava a hipótese da expressão de Westermarck. Para Lévi-Strauss, a chave dessa questão não está no ônus que a endogamia pode oferecer, mas sim nos benefícios proporcionados pela exogamia:

A exogamia tem um valor menos negativo do que positivo, afirma a existência social de outrem, e só proíbe o casamento endógamo para introduzir e prescrever o casamento com um grupo diferente da família biológica. Certamente não é porque algum perigo biológico se ligue ao casamento consanguíneo, mas porque do casamento exógamo resulta um benefício social (Lévi-Strauss, 1982, p. 521)

Tal benefício social é a aliança entre dois grupos. As mulheres, por essa perspectiva, são vistas como valores de troca, ou seja, ao proibir o seu casamento com os homens de sua própria família, esta é forçada a oferecê-las em matrimônio a outro grupo, esperando-se deste o mesmo em retribuição. Dessa forma, doando e recebendo esposas é que as partes envolvidas poderiam estabelecer fortes alianças entre si, alianças de sangue, por assim dizer, possibilitando a sua perpetuação. Portanto, para Lévi-Strauss, "considerada do ponto de vista mais geral, a proibição do incesto exprime a passagem do fato natural da consanguinidade ao fato cultural da aliança” (id., ibidem, p. 70)

Porém, para afirmar o tabu do incesto como parte de um sistema que "assegura o domínio do social sobre o biológico, do cultural sobre o natural" (id., ibidem, p. 519), como dita a teoria da aliança, é preciso negar a existência de uma tendência inata à aversão aos desejos sexuais entre parentes próximos. Para o autor tal tendência existiria apenas no imaginário de Westermarck, e outros defensores de tal ideia: "Não há nada mais duvidoso que esta suposta repugnância instintiva” (id., ibidem, p. 55). Mas será que a possibilidade de tal "repugnância instintiva" existir é tão absurda como postula Lévi-Strauss? Não existiriam talvez, ao contrário do que o autor estruturalista supóe, boas razóes biológicas para que a natureza direcionasse a escolha dos parceiros sexuais?

A seguir, tentaremos discutir mais a fundo tais questôes, mantendo o foco em alguns conceitos biológicos essenciais para entendê-las. Porém, é preciso frisar que o que se pretende aqui não é tomar a antropologia apenas como resultado de modelos biológicos. Do mesmo modo que a física e a química têm papeis essenciais na construção da biologia, mas que essa não pode ser entendida em sua completude apenas pelo estudo daquelas disciplinas, as ciências sociais também não podem ignorar a importância da biologia para a construção de seu objeto de estudo. É mais do que claro que reduzir a análise a apenas essa área do conhecimento acarretaria 
em grande perda de informaçóes. Dessa maneira, esperamos que a revisão feita a seguir também permita o acúmulo de conhecimento na antropologia e disciplinas correlatas, possibilitando assim uma abordagem mais holística sobre o tema do tabu do incesto.

Como veremos a seguir, uma das abordagens que a biologia oferece à questão da escolha de parceiros sexuais é a do "exocruzamento ótimo", como apresentada pelo etólogo Patrick Bateson (2005). Consciente das acusaçóes que os seus colegas humanistas podem fazer a um etólogo, Bateson deixa claro que considera inadequada a utilização de termos como "estupro" ou "casamento" para descrever comportamentos animais:

Problemas de comunicação entre disciplinas surgem quando, tendo achado algumas semelhanças descritivas entre animais e humanos e tendo investigado os casos animais, biólogos ou seus popularizadores usam as descobertas animais para "explicar" o comportamento humano (Bateson, 2005, p. 24, tradução nossa).

Se trata, portanto, de alguém absolutamente consciente dos perigos de uma eventual antropomorfização das pesquisas etológicas. Seguindo na mesma direção, neste texto convencionamos que a expressão tabu do incesto será utilizada para se referir exclusivamente às normas culturais que condenam a relação sexual e o casamento entre determinados parentes, sejam eles biológicos ou classificatórios ${ }^{1}$. Aversão ao endocruzamento será a expressão utilizada para se referir ao comportamento que torna menos provável a ocorrência de relaçóes sexuais entre parentes próximos, quer seja entre humanos quer seja entre os demais animais. A questão que se coloca em seguida é qual a re- lação existente entre esses dois fenômenos, se é que existe alguma. Mas antes vejamos qual é o modelo do "exocruzamento ótimo".

Os resultados do endocruzamento são em grande medida prejudiciais aos indivíduos que o praticam. Isso se deve, principalmente, ao fato de muitos genes terem alelos recessivos prejudiciais que só se expressam em homozigose (duas cópias iguais do alelo, uma vinda da mãe e outra do pai). Portanto, quanto mais aparentados os progenitores, maiores serão as chances de passarem os mesmos alelos para seus filhos e consequentemente, maior a probabilidade de ocorrer homozigose de alelos deletérios. Por outro lado, o exocruzamento excessivo também pode ser prejudicial. Afinal, tal comportamento prejudicaria a manutenção de certas características benéficas que foram adaptativamente fixadas na população.

Para exemplificar como o endocruzamento pode se tornar um jogo de ganho e perda, tomemos o trabalho de Denic et al. (2008), em que se demonstrou que em regióes com alto índice de malária o aumento da frequência de $\alpha^{+}$-thalassemia, como consequência dos casamentos consanguíneos, favorecia a resistência ao plasmódio causador da doença. Porém, essa prática também aumentava a expressão de outros alelos recessivos e letais, elevando a mortalidade infantil. Existe, portanto, pressão evolutiva partindo dos dois lados: tanto um desvio muito grande no sentido do endocruzamento quanto para o do exocruzamento trará malefícios. Por outro lado, o comportamento que determina a proporção entre endo e exocruzamento é a preferência sexual dos indivíduos. A preferência sexual por aqueles que sejam muito diferentes dos parentes próximos leva a uma situação em que o exocruzamento é mais presente. Já o contrário proporciona uma situação em que o endocruzamento prevalece. Portanto, para que haja o equilíbrio, é preciso 
i 8 | José Francisco Carminatti Wenceslau e André Strauss

haver uma tendência aos indivíduos preferirem sexualmente aqueles que sejam um pouco diferentes dos seus parentes próximos, mas não muito.

O que esse modelo mostra é que a aversão ao endocruzamento deve ter sido selecionada evolutivamente pois aqueles que possuíam tal aversão atingiam um maior sucesso reprodutivo. Ou seja, existe uma boa razão do ponto de vista evolutivo para que a aversão ao endocruzamento esteja presente entre diversos animais, inclusive o homem. Um estudo de caso que comprova tal hipótese é o de Helgason et al. (2008). Nele, os autores partiram de outras pesquisas mostrando que casais que compartilhavam algum grau de parentesco tendiam a ter mais filhos do que os que não. Porém, como ainda havia muita incerteza de que isso era resultado de fatores biológicos ou socioeconômicos, eles analisaram todos os casais islandeses com pessoas nascidas entre 1800 e 1965, a fim de se focar na influência biológica sobre a fertilidade desses casais, já que essa é uma sociedade pequena e uma das mais socioeconomicamente e culturalmente homogêneas do mundo.

Observando um total de 160.811 casais e calculando o grau de parentesco entre eles, bem como o número de filhos, percebeu-se uma relação monotônica entre esses dois fatores, ou seja, quanto menor o grau de parentesco menor o número de filhos. Contudo, quando analisado o sucesso reprodutivo dos filhos desses matrimônios, um fato curioso foi constatado, casais com parentesco maior ou igual ao de primos de segundo grau $(r \geq 0,0313)^{2}$ tinham poucos netos se comparados aos de terceiro ou quarto grau $(0,0313 \geq \mathrm{r} \geq 0,0020)$ (e até mesmo quinto e sexto, $0,0020 \geq r \geq 0,0001$ ), sem contar que a expectativa de vida para esses indivíduos era significativamente menor do que a de graus de parentesco menores. Portanto, pode-se inferir desses resultados uma expressiva relação entre parentesco e sucesso reprodutivo nessa população, esse sendo otimizado entre casais com grau de parentesco semelhantes ao de primos de terceiro e quarto grau.

Repare que nada foi dito sobre o tabu do incesto até aqui. Não se pode transferir as conclusões obtidas sobre a aversão ao endocruzamento para a questão do tabu do incesto. Antes que se tente estabelecer alguma relação entre esses dois fenômenos é preciso, do ponto de vista evolucionista, descobrir se o tabu do incesto oferece ou náo vantagens reprodutivas àqueles que o praticam.

Para Bateson, tais vantagens, se existirem, são tão pequenas que não podem ser a causa do tabu. Ele lembra, assim como fez Lévi-Strauss, que esse tabu não elimina os genes recessivos prejudiciais. Pelo contrário, o próprio endocruzamento eliminaria tais genes no longo prazo. Por outro lado, e isso náo é colocado por Bateson, a evolução não consegue prever aquilo que está por vir e, portanto, não atua a longo prazo. No curto prazo os efeitos do endocruzamento são maléficos e bastante visíveis. Tal visibilidade pode ser, inclusive, uma das razóes para que em muitas sociedades se saiba perfeitamente os efeitos biológicos adversos resultante do endocruzamento, ainda que isso não explique de maneira alguma a proibição do incesto.

Mais do que saber se o tabu do incesto oferece vantagens reprodutivas ou não, é preciso deixar claro que a distinção entre tabu do incesto e aversão ao endocruzamento não é meramente semântica. O modelo do "exocruzamento ótimo", darwinista por excelência, indica vantagens evolutivas apenas para aqueles que não se reproduzem com seus parentes próximos. Ele não diz absolutamente nada sobre indivíduos proibirem outros de fazerem o mesmo. E nesse sentido, mesmo que todos os seres humanos fossem conscientes das potencialidades prejudiciais do endocruzamento, 
isso não levaria automaticamente à conclusão de que uma proibição mútua devesse existir. Entretanto, isso não significa que ambos os fenômenos em questáo sejam dissociados. $\mathrm{O}$ próprio Lévi-Strauss sabia perfeitamente que a existência de tal aversão inata acarretaria em profundas consequências para qualquer teoria sobre a proibição do incesto. Se realmente existir uma tendência inata nos seres humanos para a aversão sexual entre parentes próximos, o tabu do incesto não pode mais ser visto como a proibição cultural de algo que seria natural ao ser humano. É importante ter em mente que não se pode instituir aquilo que já está instituído e neste sentido a afirmação clássica de Lévi-Strauss de que o tabu do incesto é o nexus social instituinte fica, no mínimo, prejudicada. Tal perspectiva coloca em xeque uma das suposiçóes mais enraizadas nas ciências humanas:

Não é fácil ver porque qualquer instinto humano profundo precisaria ser reforçado pela lei. Não há nenhuma lei mandando que o homem coma ou beba ou proibindo o homem de por suas mãos no fogo... A lei apenas proíbe o homem de fazer aquilo que os seus instintos o inclinam a fazer; o que a natureza por si só proíbe e pune, seria supérfluo que a lei proibisse e punisse (Frazer, 1910).

Esse argumento é muito difundido dentre os cientistas sociais, em Lévi-Strauss, essa ideia também aparece: "Não existe nenhuma razão para proibir aquilo que, sem proibição, não correria o risco de ser executado" (Lévi-Strauss, 1982, p. 56). Mais do que presente, essa ideia é absolutamente necessária para a sua teoria. Afinal, para ele, a cultura surge ao ocupar o espaço vazio deixado pela natureza a partir do momento em que essa deixa que as alianças se estabeleçam ao acaso. Daí a enorme importância da questão da existência ou não de uma aversão inata ao endocruzamento.

É de fundamental importância, portanto, ver quais são as evidências que apontam para a existência ou não de uma aversão sexual entre aqueles que conviveram nos primeiros períodos da vida. Vale notar que as evidências que em seguida serão expostas em nada dependem do modelo do exocruzamento ótimo ser correto ou não. Primeiramente visitaremos os nossos parentes filogenéticos mais próximos e observaremos qual é o comportamento deles no que diz respeito à aversão ao endocruzamento. Em seguida, observaremos nossa própria espécie em busca de evidências antropológicas que sustentem essa hipótese.

Antes de iniciar a análise propriamente dita do comportamento de alguns primatas no que diz respeito à aversão ao endocruzamento é bom que se explique para aqueles que não estão familiarizados com o pensamento darwinista a importância e o que se espera de tais tipos de estudo. Anne Pusey, que nos ajudará nessa fase do trabalho, resume em poucas palavras aquilo que a primatologia pode oferecer: "Se os primatas, nossos ancestrais vivos mais próximos, evitam o endocruzamento, essa descoberta evidencia que esse comportamento precede as práticas culturais humanas" (Pusey, 2005, p. 61, tradução nossa). O próprio Lévi-Strauss estava absolutamente ciente da importância de se observar como os macacos antropoides se comportavam. Entretanto, o autor francês chegou à conclusão de que em nada tais observaçóes poderiam contribuir para a compreensão dos fenômenos humanos. Segundo ele, a imprevisibilidade do comportamento dos macacos 
20 | José Francisco Carminatti Wenceslau e André Strauss

antropoides, tanto individualmente quanto coletivamente, revelava um vazio deixado pela dissolução dos instintos, mas que não fora preenchido. Vejamos como o próprio Lévi-Strauss argumenta sobre o comportamento de macacos: "Não somente o comportamento do mesmo sujeito náo é constante, mas não se pode perceber nenhuma regularidade no comportamento coletivo" (Lévi-Strauss, 1982, p. 45)

Mais importante ainda é o fato de Lévi -Strauss utilizar o comportamento dos primatas como o argumento derradeiro para negar Westermarck:

Sejam quais forem as incertezas a respeito dos costumes sexuais dos grandes símios e do caráter monogâmico ou poligâmico da família entre os gorilas e os chimpanzés, é certo que estes grandes antropoides não praticam nenhuma discriminação sexual com relação a seus parentes próximos (id., ibidem, p. 71).

A negação de Westermarck é, para a teoria de Lévi-Strauss, muito mais do que um mero capricho argumentativo. Afinal, se a aversão sexual por parentes próximos for inata, como propóe Westermarck, a natureza passa a dizer algo sobre o fenômeno que era para Lévi-Strauss de domínio exclusivo da cultura, notadamente a aliança:

Ora, se admitirmos, de acordo com a evidência, a anterioridade histórica da natureza em relação à cultura, somente graças às possibilidades deixadas abertas pela primeira é que a segunda pôde, sem descontinuidade, inserir sua marca e introduzir suas exigências próprias... Mas a cultura, impotente diante da filiação, toma consciência de seus direitos, ao mesmo tempo que de si mesma, diante do fenômeno, inteiramente diferente, da aliança, o único sobre o qual a natureza já não disse tudo (id., ibidem, p. 71).

Mesmo mais de 50 anos depois da publicação da primeira edição de As estruturas elementares do parentesco, pode-se ouvir do autor que "o conhecimento acerca dos grandes símios nos ensina pouco sobre o passado humano, tanto próximo quanto distante" (Lévi-Strauss, 2000; nossa tradução). Nesse argumento, Lévi-Strauss diz que a proximidade filogenética entre nós e os grandes símios não diz nada sobre a evolução do nosso comportamento. Para ele, isso deveria ser estudado apenas analisando os nossos ancestrais - e não parentes próximos - no entanto, ele se esquece de que na biologia análises comparativas entre espécies podem trazer informaçóes esclarecedoras. Especialmente no que tange aos estudos primatológicos, de maior relevância para este trabalho, o seu diálogo cada vez maior com a antropologia já ofereceu provas suficientes de que eles podem sim trazer-nos algo novo a respeito do comportamento humano. Vejamos.

Entre os primatas o cruzamento entre parentes de primeira ordem quase nunca ocorre. Basicamente existem duas razóes para isso. A primeira delas é que a maioria dos primatas, assim como muitos outros animais, deixam seu grupo natal antes de se tornarem adultos e portanto é raro que dois indivíduos de sexos opostos que sejam parentes de primeira ordem convivam quando sexualmente maduros (Pusey, 2005). A outra razão é que - e é essa razão que nos interessa no momento - mesmo se esses dois indivíduos conviverem, eles não estabelecerão relações sexuais entre si.

$\mathrm{Na}$ maioria das espécies de primatas o padrão de dispersão é os machos abandonarem seu grupo natal. Casos documentados desse tipo de dispersão incluem o dos babuínos do Parque Nacional do Gombe, macacos-prego, lêmures e várias espécies de "macacos inferio- 
res”. Algumas espécies, como os chimpanzés, macacos aranha, muriquis e colobus vermelhos apresentam o padrão oposto, com as fêmeas deixando o grupo natal (Packer, 1995). A dispersão pode ser explicada como um comportamento fixado evolutivamente para evitar o endocruzamento. Outra hipótese é que a dispersão seria resultado da competição interna no grupo. Ainda que não seja possível escolher uma das hipóteses com absoluta certeza de que a outra esteja errada, o fato dos indivíduos se transferirem para um outro grupo justamente no período fértil (no caso de ser fêmea) acrescido do fato de que os indivíduos não são expulsos do grupo original e são recebidos com hostilidades pelo novo grupo, oferecem indícios de que a primeira alternativa esteja mais próxima ao que de fato acontece (Pusey, 2005).

Ainda que esses padrões de dispersão reduzam significantemente as chances do endocruzamento ocorrer, algumas vezes indivíduos de primeira ordem de parentesco e de sexos opos- tos convivem durante o período em que ambos estão sexualmente maduros. Estudos de longa duração entre os primatas revelam que mesmo em tais circunstancias é raro que ocorram relaçôes sexuais entre parentes próximos. A Tabela 1, adaptada a partir do texto de Pusey (2005), resume tais estudos. De maneira geral fica claro que quase não ocorrem endocruzamentos matrilineares. Com relação ao endocruzamento patrilinear os dados são menos claros, até porque muitas vezes é difícil identificar quem é o progenitor. Ainda assim, no caso dos gorilas em que tal identificação é possível, são raros os casos de relaçóes entre pais e filhas. Por outro lado, pesquisas feitas utilizando o DNA para identificar os progenitores revelaram que entre macacos-rhesus e macacos-de-gibraltar criados em cativeiros o índice de endocruzamento patrilinear não era maior do que o cruzamento com os demais indivíduos do grupo.

Mais significativo ainda é o fato da aversão ao endocruzamento algumas vezes não se limitar às

Tabela 1. Aversão a atividade sexual entre parentes (adaptado de Pusey, 2005).

\begin{tabular}{|c|c|c|c|c|c|}
\hline Espécie & Mãe & Irmão/a materno & Outros parentes maternos & Pai & Irmão/a Paterno \\
\hline $\begin{array}{l}\text { Lémures-de-cauda- } \\
\text { anelada }\end{array}$ & - & - & & & \\
\hline Muriquis & - & & & & + \\
\hline Saguis & - & & & - & \\
\hline Macacos Vervet & - & - & - & & \\
\hline Macacos-japonêses & - & - & - & & \\
\hline Macacos-rhesus & - & - & - & - & + \\
\hline $\begin{array}{l}\text { Macacos-de- } \\
\text { Gibraltar }\end{array}$ & - & - & - & + & + \\
\hline Macaca arctoides & - & - & & & \\
\hline Babuínos-anúbis & - & - & & - & \\
\hline Papio cinocephalus & - & - & - & & - \\
\hline Chimpanzés & - & - & & $+/-$ & \\
\hline Gorilas & & & & - & \\
\hline
\end{tabular}

- significa que ocorre inibição de cópula, + significa que ocorre a cópula, +/- significa que ocorre entre alguns pares mas não entre outros. Espaços vazios significam que não foram obtidos dados de frequência de cópula para a espécie em questão 
atividades heterossexuais. A observação por mais de dez anos de grupos cativos de macacos-japoneses, conhecidos pelos hábitos homossexuais de suas fêmeas, evidenciou relaçóes homossexuais entre fêmeas não relacionadas, mas não entre irmãs, mãe e filha, e avó e neta (Chapais \& Mignault, 1991). Portanto, isso pode ser um "subproduto" da hipótese da adaptação no modelo de Westermarck, já que não há problema algum em se esperar que a aversão à relação sexual durante a vida adulta se estenda a todos os indivíduos com os quais se teve contato durante a infância, sejam eles machos ou fêmeas.

Além de oferecer fortes indícios de que existe uma aversão natural ao endocruzamento, os estudos com primatas também ajudam a resolver uma outra questão. Para que tal aversão exista é preciso que os indivíduos sejam capazes de reconhecer seus parentes. Os pesquisadores conhecem basicamente duas maneiras através das quais tal reconhecimento pode ser feito. A primeira delas é através da comparação fenotípica. Ou seja, cada indivíduo compara alguma característica determinada de um outro indivíduo, o odor por exemplo, consigo próprio. Através do grau de semelhança entre as características seria possível que o indivíduo identificasse o grau de parentesco, pois existe uma forte correlação entre o grau de compartilhamento genético e o fenótipo.

O outro mecanismo possível é aquele em que sáo considerados parentes os indivíduos que estiveram intimamente associados durante a imaturidade. Em algumas espécies de mamíferos a associação durante a imaturidade chega a ser mais importante do que o grau biológico de parentesco no que diz respeito à escolha do parceiro. Entre os primatas parece ser essa a explicação que melhor se encaixa às observaçôes. $\mathrm{O}$ vínculo entre mãe e filho é intenso e prolongado, o que reflete no fato de serem quase inexpressivos os casos de endocruzamento entre mães e filhos sexualmente maduros. Já as relaçôes entre pai e filhas em mui- tas espécies de primatas é praticamente inexistente. O que se observa é exatamente o previsto pela teoria. Ou seja, a cópula entre pais e filhas sexualmente maduras não chega a ser uma raridade. Exceção que confirma a regra são os gorilas e os macacos marmoset. Os laços entre pais e filhas entre essas espécies é mais forte do que entre as demais. Isso acontece entre os primeiros pois os machos possuem acesso reprodutivo exclusivo ao grupo de fêmeas e entre os segundos por serem monogâmicos. Em ambas as espécies existe uma forte aversão ao endocruzamento patrilinear, exatamente como seria de se esperar pela hipótese da associação de Westermarck, já que nesses casos - e nos anteriores - ela surge das relaçóes de fraternidade, e não do parentesco per se.

Pesquisas feitas entre chimpanzés trazem informaçóes que tornam bastante plausível a classificação da aversão ao endocruzamento como um fator de adaptação dentro dos hábitos de seleção sexual. Observações sobre a ontogenia dos chimpanzés, assim como de outros primatas, revela que antes da maturidade sexual o cruzamento entre mães e filhos é um fenômeno razoavelmente frequente, chegando a ser responsável por cerca de $5 \%$ a $7 \%$ do total de relaçôes sexuais da mãe durante o período em que ela está sexualmente receptiva. É importante observar que, apesar de ejacularem apenas a partir dos nove ou dez anos, chimpanzés com até mesmo três anos de idade são capazes de efetuar a cópula, que obviamente náo pode resultar na gravidez da parceira. É justamente a partir dos sete ou oito anos que a aversão ao endocruzamento matrilinear começa a se fazer fortemente presente. São raríssimos os casos em que tais relaçóes são estabelecidas (Pusey, 2005).

A partir dessa breve exposição sobre a etologia de nossos parentes primatas, podemos encontrar algumas homologias comportamentais. A aversão ao cruzamento entre parentes próximos é sentida mais fortemente pelas fêmeas 
do que pelos machos, afeta tanto as relaçóes homo como heterossexuais, diminui com o grau de parentesco e geralmente impede o intercurso entre indivíduos maduros, sem impedir as brincadeiras sexuais da infância. Chapais (2010) propóe que, da mesma forma que as homologias anatômicas, essas homologias comportamentais também podem ser usadas para investigar a nossa história evolutiva.

Por exemplo, dados sobre Papio hamadryas (babuíno hamadrias) mostraram que os grupos dessa espécie também são exogâmicos e virilocais (Colmenares, 2004). A diferença é que entre humanos essa exogamia tem implicaçóes para todo o grupo, como por exemplo, a aliança entre eles (Lévi-Strauss, 1982). No caso dos primatas, há uma afinidade entre o novo grupo e a fêmea que partiu. Já em humanos, o grupo da mulher também adquire reconhecimento (afinidade bilateral). Segundo Rodseth (1991), isso só é possível graças à comunicação simbólica, mas especificamente, ao que ele chama de displacement, a capacidade de se referir a coisas em outros lugares e tempos. Os mecanismos de aversão ao endocruzamento, portanto, já existiam no passado evolutivo humano, apenas se complexificando e recebendo uma carga simbólica em nossa espécie, como o próprio surgimento do tabu do incesto. Robin Fox, antropólogo social, chega a compartilhar dessa ideia ao dizer que a humanidade não inventou o parentesco e a aversão ao incesto, mas outros componentes da exogamia, como exocruzamento, parentesco não-sanguíneo e troca de esposas. As relaçóes de parentesco já presentes em nossos antepassados, juntamente com as atribuições simbólicas humanas, foram o que deram origem às relaçôes classificatórias como as conhecemos hoje (Fox, 1980). Segundo Fox, portanto, o tabu do incesto trata das relaçóes sexuais e das regras de exogamia, e, ao contrário do que assume Lévi-Strauss, uma não implica na outra. Assim, a moral por trás do tabu do incesto pode ser vista como um investimento simbólico humano sobre uma resposta adaptativa trazida à tona durante nosso passado primata, o que retoma a perspectiva socrática: as leis do incesto viriam, não para controlar uma propensão humana, mas sim para reforçar uma aversão natural.

Mesmo com uma exposição tão rápida quanto essa, é impossível não perceber a pertinência dessas observaçóes etológicas para a compreensão do fenômeno social. Lévi-Strauss sabia disso, entretanto ele escreveu seu doutorado uma década antes das pesquisas de longa duração sobre os primatas sequer terem início. Ele baseou sua obra científica nas evidências que estavam disponíveis em sua época, nada mais inevitável. Menos inevitável, porém, é que, após 60 anos as mesmas evidências continuem sendo apresentadas sem serem alvo de qualquer espécie de atualização. Dessa forma, uma impressão anacrônica sobre as potencialidades da etologia acaba se fixando na mente dos estudantes. Obviamente, tal efeito nefasto não tem origem exclusiva na leitura de $A s E s$ truturas Elementares do Parentesco, mas mesmo assim esse é um dos momentos em sala de aula em que ocorre a transmissão de preconceitos autorizados. É preciso que os professores abordem esse tipo de produção de conhecimento, mesmo que a primeira vista ele náo esteja relacionado diretamente às ciências sociais. Somente dessa forma é que se pode combater o insulamento acadêmico e proporcionar a amplamente anunciada interdisciplinaridade.

Saindo do foco da etologia, vejamos agora uma das pesquisas que procura entre os próprios seres humanos indícios dessa aversão ao endocruzamento. Arthur Wolf é um sinólogo 3 
que encontrou numa tradição chinesa fatos reveladores sobre os efeitos da convivência durante a imaturidade sobre a vida conjugal de duas pessoas. Até a metade do século XX, as famílias chinesas podiam optar entre duas maneiras para conseguir uma esposa para seus filhos. Uma delas consistia em esperar o filho crescer e então arranjar um casamento com uma determinada jovem que viria morar com seu marido e sogros. Nesses casamentos, que Wolf (2005) chama de "casamentos maiores", noiva e noivo se conheciam apenas no dia do casamento.

Em contrapartida, a família poderia optar por aquilo que Wolf chamou de "casamentos menores". Nesse tipo de casamento uma pequena garota seria adotada, muitas vezes comprada, e criada como se fosse uma filha naquela família. Muitas vezes tais garotas eram adotadas em idade tão precoce que suas futuras sogras as ninavam. Não chegava a ser raro a situação em que as mães davam suas filhas biológicas para poderem cuidar da futura nora - sim-pua é o nome dado pelos taiwaneses a essas garotas, que significa "pequena nora". Conforme relata Wolf (2005), em 1905 o governo colonial japonês em Taiwan entrevistou cada pessoa da ilha perguntando a data de nascimento, a data de adoção, e a forma e data do casamento atual. A partir de então as vilas passaram a ser obrigadas a relatar com no máximo dez dias de atraso todos os eventos vitais como nascimentos, falecimentos, casamentos e divórcios. Dessa maneira, a política colonial japonesa legou um banco de dados espetacular sobre a vida dos taiwaneses.

Arthur Wolf trabalha com esses dados há mais de quarenta anos e já analisou mais de 20.000 casamentos. Para ele, existem duas conclusôes claras a que se pode chegar: as sim-pua que foram adotadas em uma idade precoce apresentaram uma fertilidade cerca de $40 \%$ menor e uma chance de se divorciar cerca de três vezes maior do que as mulheres dos "casamentos maiores". Além disso, em entrevistas referentes à vida extraconjugal de 551 mulheres, Wolf descobriu que, segundo os parentes e os vizinhos, mulheres que se casaram com homens com os quais compartilharam a infância eram duas vezes mais propícias a procurarem satisfação sexual fora do casamento do que aquelas que casaram com homens com os quais não compartilharam a infância.

Com a ajuda de dados censitários podemos estender a discussão a respeito do incesto ainda mais longe no passado. No Egito durante o domínio romano, em torno de 300 e 100 a.C., era comum se fazer um levantamento censitário de todas as unidades domésticas da região. Alguns desses levantamentos, registrados em papiros, sobrevivem até hoje, sendo uma fonte rica de informação para o nosso debate. $\mathrm{O}$ casamento entre irmãos era muito comum nessas ocasióes. Walter Scheidel (2005), em seu levantamento, conseguiu dados referentes a 121 casamentos censitados, desses, 20 eram entre irmãos e quatro entre meio-irmãos, além de outros $13 \mathrm{ca}$ sos também relatados em outros documentos. Nesse caso, o casamento entre irmãos era uma norma cultural, sendo inclusive uma forma preferencial de casamento entre as múltiplas geraçôes dinásticas (Middleton, 1962).

Meyer Fortes (1983) e Edmmund Leach (1991) chegaram a utilizar esses casamentos como uma prova contra o efeito Westermarck. Porém, Scheidel apresenta argumentos de que mesmo estes casos estão de acordo com a teoria. Segundo o autor, as mulheres dessa época tinham, no auge de sua idade reprodutiva, filhos de três em três anos (em média). Intervalos menores do que esses poderiam ser resultado de um hábito comum nesse tempo: as amasde-leite tiravam o fardo da amamentação das mães e faziam com que essas voltassem ao seu ciclo reprodutivo mais cedo. Segundo o que 
foi observado nos papiros, os casamentos mais comuns entre irmãos eram entre aqueles com média de sete anos ou mais de diferença. Essa diferença de idade era suficiente para que eles não convivessem tão intimamente a ponto de surgir uma aversão sexual entre ambos. Ademais, com exceção de dois casamentos, em todos os outros em que se podia identificar a idade dos noivos, $o$ homem era mais velho, já que as filhas ajudavam a mãe nos cuidados com os irmãos mais novos, tendo assim com esses últimos contato mais frequente, atitude propícia para o surgimento de uma aversão sexual na maturidade.

Como Wolf (2005) observou, essa aversão é mais acentuada se a associação acontece antes dos três anos de idade. No Egito romano, o casamento entre irmãos com diferença de idade menor do que essa só seria possível se pelo menos um deles tivesse sido amamentado por uma ama-de-leite, para que a mãe tivesse condições de conceber o segundo filho. Scheidel (2005) propóe que a amamentação por outra mulher faz com que a criança passe a não reconhecer olfativamente o $\mathrm{MHC}^{4}$ de sua mãe. Estudos com camundongos mostram que na idade adulta, esses animais passam a ter uma aversão reprodutiva por indivíduos que tenham odores semelhantes àqueles de sua ninhada (Yamazaki et al, 1988; Eklund, 1997). Da mesma forma, a criança passaria então a sentir uma aversão a odores compatíveis com o MHC de quem a amamentou, e não mais ao de sua própria família. No entanto, como o próprio autor reconhece, apesar de já ter sido provada em outros animais, a associação entre a formação de uma identidade olfativa na infância e preferências sexuais na vida adulta ainda precisa ser estudada mais a fundo em humanos para que então se possam fazer tais afirmaçôes com maior segurança.

Para agregar mais informaçôes a esse debate, podemos recorrer ainda a um terceiro estudo, clássico, entre os kibbutzim israelenses. Nesses grupos, a fim de se fazerem mais igualitários e reduzir a divisão sexual do trabalho, bem como diminuir a importância dada à família, visando a produção de uma sociedade mais comunitária, é comum criar um grupo de crianças de ambos os sexos e com diferenças de idade menor que um ano em um mesmo kvutza - casas sob a supervisão de algumas mulheres, podendo ou não ser mães de alguns deles. Devido a esse grande comprometimento ideológico, não existe distinção sexual nas atividades realizadas pelas crianças. Ambos os sexos se vestem da mesma maneira, recebem a mesma educação, dormem nos mesmos quartos e usam os mesmos banheiros, além de crescerem em um ambiente permissivo quanto à nudez e ao sexo (Berghe, 1983). Apesar de não haver nenhuma norma restringindo o casamento ou relaçóes sexuais entre membros de um mesmo kvutza, Joseph Shepher, ao analisar o comportamento sexual e os padróes matrimoniais entre adolescentes e adultos de Yaara (nome fictício dado ao kibbutz estudado), evidenciou que não havia nenhum caso de relações heterossexuais entre membros de uma mesma casa. Além disso, dentre os 2.769 casamentos envolvendo kibbutzniks, não se encontrou nenhum entre indivíduos criados no mesmo kvutza (Shepher, 1971). Quando questionados a esse respeito, kibbutzniks atribuíam a falta de atração erótica entre eles à uma sensação de fraternidade para com seus companheiros de criação. Portanto, da mesma maneira que entre os taiwaneses, a convivência desde a tenra infância pode ter levado a um imprinting negativo entre os membros dessas comunidades.

E a nossa própria sociedade, o que será que ela tem a nos dizer sobre a aversão ao incesto? Mark Erickson (2005) fez um bom apanhado sobre a realidade social do incesto, por assim dizer. Conforme ele mesmo nota, ao mesmo tempo em que os biólogos foram percebendo 
a raridade do incesto entre os animais, os médicos constataram que a ocorrência do incesto na sociedade ocidental era bem maior do que se imaginava. Será entâo que as sociedades ocidentais fornecem evidências que neguem a aversão inata ao incesto? Como veremos a seguir esse não é necessariamente o caso. Antes de mais nada, Mark Erickson mostra as diversas estimativas que foram feitas sobre a extensão em que o incesto ocorre nas sociedades ocidentais.

Dos estudos que ele apresenta, cinco foram feitos nos Estados Unidos, um na Inglaterra, um na Finlândia e um na Suíça. Cada um deles utilizou metodologias diferentes. Em algumas pesquisas a ocorrência do incesto só era considerada se as relaçóes chegassem a penetração ou sexo oral. Já outros estudos consideravam incesto também os casos de molestamento e até mesmo de insinuações. Apenas as relaçóes incestuosas entre parentes biológicos foram levadas em conta nesses estudos. Entretanto, é bom relembrar que os padrastos tem muito mais chances de perpetrarem um ato incestuoso do que o pai biológico, já que nesses casos há maiores chances de não ter havido contato tão frequente entre ambos durante os primeiros anos de vida da afilhada. Isso posto, Mark Erickson inicia sua análise das relações incestuosas. Ele propõe que possam existir diferentes tipos de relaçóes dessa natureza. Em um dos casos o incesto ocorre entre indivíduos que conviveram durante a infância de pelo menos um deles, noutro os indivíduos foram separados quando ainda crianças. De acordo com a hipótese da aversão de Westermarck como engendradora de uma repulsão ao endocruzamento, seria de se esperar que ambos os casos fossem diferentes entre si. Vejamos o que as observações nos dizem a respeito disso.

Os casos de incesto entre indivíduos que estiveram associados desde a infância de um deles revela uma quase homogeneidade com relação a alguns fatores. Primeiramente, essas famílias incestuosas tendem a ter maior presença de alcoolismo, uso de drogas e discordância marital. Mais do que isso, os pais são quase sempre negligentes e emocionalmente indisponíveis. É muito comum que os pais incestuosos tenham tido uma infância traumática em que foram negligenciados de alguma forma. Numa pesquisa feita por McCarty sobre relações incestuosas entre mães e filhos, que é extremamente rara, 95\% das mães entrevistadas haviam sofrido algum tipo de abuso durante a infância. No caso do incesto de pai e filha a experiência é invariavelmente iniciada pelo pai e a filha nunca sente prazer. As filhas geralmente descrevem a experiência como sensação de medo, desgosto, confusão, raiva ou vergonha. No caso de incesto entre irmãos as coisas são bastante parecidas: pais ausentes e abusos durante a infância (McCarty, 1986). Naomi Adler e Joseph Schultz descobriram em sua pesquisa que $92 \%$ dos garotos que haviam perpetrado o incesto sofreram algum tipo de abuso de pelo menos um dos pais (Adler \& Schutz, 1995). Vale a pena notar que as relações pessoais entre irmão e irmã que tiveram relaçóes incestuosas geralmente são nulas no que vai além do incesto e do abuso sexual propriamente dito.

Pierre von der Berghe, ao revisar alguns trabalhos sobre incesto e abuso sexual em sociedades ocidentais, assim como Erickson, constatou que a grande maioria dos casos era composto por pais e filhas e irmãos mais velhos e irmãs mais novas, os homens sempre agindo como agressores. Dentre as várias hipóteses que podem explicar tal constatação, o autor se foca em uma, a de que a ausência do surgimento de um imprinting aversivo pelos membros dessas famílias como resultado de uma estrutura familiar pouco coesa e a acentuada diferença de idade (nos casos entre irmãos) refletir-se-ia mais acentuadamente entre os homens. Para ele, além de sua maior agressividade, promiscuidade, idade e status social, bem como a sua 
própria anatomia facilitar a coerção sexual, haveria um "investimento parental assimétrico" (Berghe, 1983), ou seja, devido à sua baixa produção de gametas e alto nível de investimento na prole, é muito mais custoso para a mulher ter relaçóes sexuais com parentes próximos - e arcar com as consequências reprodutivas - do que para o homem. Tanto, que muitas dessas vítimas fogem de casa ou decidem colocar um fim nos abusos apenas após a puberdade, na maioria dos casos fugindo, casando ou tendo um filho com outro homem (Berghe, 1983).

Quando voltamos nossas atenções para os casos de incesto entre parentes que foram separados quando ainda pequenos e só se reencontraram quando adultos as coisas se revelam bem diferentes. Longe de ser uma experiência traumática para alguma das partes e longe também de ser um ato imposto ou coercitivo, esses casos de incesto são quase sempre uma experiência agradável e até mesmo irresistível. Como exemplo desse tipo de incesto vale citar os seis casais de irmãos incestuosos estudados por Weinberg (1955). Em todos eles, o relacionamento era não só consentido como também envolvia uma grande dose de paixão. Todos os irmãos desses seis casais haviam sido separados quando crianças e só se reencontraram bem mais tarde. Mais do que isso, todos sabiam perfeitamente das restriçóes sociais e legais ao incesto e nenhum deles manifestava qualquer preocupação com relação a isso. Outro exemplo que aponta na mesma direção vem dos estudos de Maurice Greenberg e Roland Littlewood sobre os reencontros entre parentes há muito tempo distantes (Greenberg \& Littlewood, 1995). Esse tipo de reencontro aumentou consideravelmente na Inglaterra após o Acess to Birth Records Act ser aprovado, em 1975, permitindo às pessoas adotadas que encontrassem seus parentes biológicos. $\mathrm{O}$ que surpreendeu os pesquisadores foi que em grande parte dos reencontros, cerca de $50 \%$, segundo suas estimativas, uma grande atração sexual foi descrita por ambas as partes. Ao que tudo indica, a atração entre parentes que não tiveram associação durante a infância é muito forte, já que eles se reconhecem; os traços físicos, os gestos e até mesmo o cheiro igual foram relatados como motivo de atração. Essa atração já é muito bem conhecida na biologia e evidenciada em outras espécies, recebendo o nome de phenotypical matching, em que os indivíduos tendem a se reproduzir com aqueles fenotipicamente parecidos.

Como resume Erickson, as observações do incesto em nossa própria sociedade oferecem, portanto, sustentação para o teoria de Westermarck:

Como previsto pela hipótese de Westermarck, estudos clínicos mostram que as chances de ocorrer o incesto são muito maiores se os parentes forem separados durante a infância. É apenas nessa circunstância que o incesto pode ser mutuamente desejado e eventualmente virar um casamento. Os tabus parecem ter influência limitada. Por outro lado, quando ocorre a associação durante as primeiras fases da vida o incesto é raramente, se alguma vez realmente o for, mutuamente desejado (Erickson, 2005, p. 170, tradução nossa).

Na realidade, o próprio complexo de Édipo, âncora das teorias freudianas sobre o incesto, também faz sentido segundo Westermarck. Como Édipo foi separado de seus pais logo após ter nascido, ele não teve a chance de experimentar o contato familiar que lhe possibilitasse a geração de uma aversão sexual à mãe. Essa aversão, não sendo despertada, abre caminho para o phenotypical matching. Édipo, então, tornar-se-ia passível de uma atração por Jocasta devido às grandes semelhanças fenotípicas entre ambos. 
Após essa análise, percebe-se que a teoria antropológica lévi-straussiana a respeito do incesto, bem como os conceitos psicanalíticos freudianos sobre o qual ela se sustenta, deixa de parecer tão concreta quanto proposto pelos cursos de estruturalismo em geral. A grande variedade de pesquisas efetuadas posteriormente a seus trabalhos, dentre as quais algumas aqui expostas, mostraram-se um forte instrumento para a derrubada do paradigma por eles sustentado. A diversidade de fontes é extensa, como mostramos, desde trabalhos com genética até correntes psicanalíticas divergentes, passando por estudos de etologia de primatas e de casos clínicos em humanos. Pode-se ver que não faltam hipóteses que contradigam essas grandes correntes mantidas durante boa parte do século XX.

No entanto, não podemos (e nem pretendemos) contestar a importância dos pontos de vista assumidos por esses autores. Não fosse pelo próprio Lévi-Strauss, provavelmente muitos dos estudos bioantropológicos, como os que tomamos como exemplo, sequer haveriam sido propostos. Devemos, contudo, entendê-los na sua época, contextualizados dentro do conhecimento científico próprio de seu tempo. Ele mesmo assume, no prefácio da $2^{\text {a }}$ edição de As Estruturas Elementares do Parentesco, a carência de estudos mais detalhados em genética para o tema por ele abordado:

Continuo a crer que a proibição do incesto explica-se inteiramente por causas sociológicas, mas é certo que tratei do aspecto genético de maneira excessivamente ligeira. Uma apreciação mais justa da taxa muito elevada das mutaçóes e da proporção das que são nocivas levaria a afirmaçôes mais atenuadas, mesmo que as consequências deletérias das uniōes consanguíneas não tiveram papel na origem ou na persistência das regras de exogamia (Lévi-Strauss, 1982, p. 25).
Assim sendo, é que nos propusemos, neste artigo, a abrir os olhos dos cientistas sociais brasileiros a outras áreas de pesquisa que não as suas, mas que também se mostram igualmente relevantes. Muitas vantagens podem surgir ao combatermos esse isolamento acadêmico e proporcionar, então, novas formas de diálogo. Apropriando-nos das palavras de Foucault, "para que exista uma disciplina deve existir a possibilidade de se formular novas proposiçóes - e de assim fazer-se ad infinitum..." (Foucault, 1976). Lévi -Strauss portanto, não é, de maneira alguma, um ponto final na questáo do Tabu do Incesto.

\section{The incest taboo and bioanthropology}

abstract The debate about the incest taboo has been widely discussed even before the foundation of anthropology as a field of study. However, it was in that area of knowledge that the theme acquired accentuated attention, especially after the publication of the renamed work of Claude Lévi-Strauss, The Elementary Structures of Kinship, in 1949. A large part of Brazilian schools of social sciences assumes this subject was ended by this author; nevertheless, this is far from being true. In this article we try to relight the debate with the Levi-Straussian structuralism and its main theory about the prohibition of incest - the alliance theory - through the selection of several studies that somehow dialogs with this author's work. Thereby, it is with special help of the boundary works between biology and anthropology - which many times don't reach the social scientists - that we hope to revive this reflection among the Brazilian academy.

keywords Lévi-Strauss. Inbreeding. Etology. Primatology. Endogamy

\section{Notas}

1. Cabe ressaltar, como faz Felipe Verde (1994) e também o próprio Lévi-Strauss (1982), que o conceito de incesto (e sua consequente proibiçáo) deve ser inter- 
pretado de maneira relativa, ou seja, uma sociedade mais permissiva quanto ao casamento entre parentes próximos náo pode ser considerada incestuosa apenas por esses hábitos serem proibidos em nossa sociedade. Ela ainda manterá suas próprias restriçôes, porém, sob uma diferente magnitude.

2. Em genética de populaçôes, o símbolo " $\mathrm{r}$ " denota a proporção de genes compartilhados entre dois indivíduos. Assim sendo, dois indivíduos com $r=0,03125$ (equivalente a primos de segundo grau) compartilham 3,125\% de seus genes devido a uma ascendência em comum.

3. A sinologia consiste no estudo dos aspectos culturais, sociológicos e políticos da China.

4. O MHC é um complexo de genes que atua principalmente no sistema imunológico, codificando proteínas para o reconhecimento de patógenos. Porém, como já comprovado em várias espécies de animais, esses genes também influenciam na produção de odores corpóreos, determinando a construção de uma identidade olfativa durante as primeiras fases da vida e levando a posteriores padrôes de seleção sexual durante a idade adulta (Havlicek \& Roberts, 2009).

\section{Referências bibliográficas}

ADLER, Naomi; SCHUTZ, Joseph. Sibling Incest Offenders. Child Abuse \& Neglect, v. 19, p. 811-819, 1995.

ARNHART, Lerry. The Incest Taboo as Darwinian Natural Right. In: WOLF, Arthur. DURHAM, William. (Orgs). Inbreeding, Incest and the Incest Taboo; the state of knowledge at the turn of the century. Stanford: Stanford University Press, 2005. p. 190-219

BATESON, Patrick. Inbreeding Avoidance and Incest Taboo. In: . (Orgs). Inbreeding, Incest and the Incest Taboo; the state of knowledge at the turn of the century. Stanford: Stanford University Press, 2005. p. 24-37.

BERGHE, Pierre L. van den. Human inbreeding avoidance: Culture in nature. The Behavioral and Brain Sciences, v. 6, p. 91-123, 1983.

CHAPAIS, Bernard. Primeval Kinship: How pair-bonding gave birth to human society. Cambridge: Harvard University Press, 2010.

CHAPAIS, Bernard; MIGNAULT, Christiane. Homosexual incest avoidance among females in captive Japanese macaques. American Journal of Primatology, v. 23, p. 171-183, 1991.

COLMENARES, Fernando. Kinship structure and its impact on behavior in multilevel societies. In: CHA-
PAIS, B. \& BERMAN, C. M. (Orgs.). Kinship and Behavior in primates. Nova York, Oxford University Press, 2004. p. 242-270.

DARWIN, Charles. The Descent of Man (Vol. 1), Londres: John Murray, 1871.

DENIC, Srdjan, NAGELKERKE, Nicolas, AGARWAL, Mukesh M. Consanguineous marriages and endemic malaria: can inbreeding increase population fitness? Malaria Journal, v. 7, p. 150-158, 2008.

EKLUND, Amy. The Effect of Early Experience on MHC-Based Mate Preferences in Two B10.W Strains of Mice (Mus domesticus), Behavior Genetics, v. 27, p. 223-229, 1997.

ERICKSON, Mark T. Evolutionary Thought and the Current Clinical Understanding of Incest. In: . (Orgs.). Inbreeding, Incest and the Incest Taboo; the state of knowledge at the turn of the century. Stanford: Stanford University Press, 2005. p. 161-189 FOUCAULT, Michel. The Discourse on Language. In: The Archeology of Knowledge, Nova York: Harper and Row, 1976. p. 224.

FRAZER, James George. Totemism and exogamy: a treatise on certain early forms of superstition and society. London: Macmillan, 1910.

FREUD, Sigmund. Totem e Tabu. In: Edição Standart Brasileira das obras de psicológicas completas de Sigmund Freud (Vol. 13). Tradução de Órizon Carneiro Muniz. Rio de Janeiro: Imago, [1913] 1974.

. Civilization and Its Discontents. Tradução de James Strachey. Nova York: Norton, [1930] 1961.

FORTES, Meyer. Rules and the Emergence of Society. Londres: Royal Anthropological Institute of Great Britain and Ireland, 1983.

FOX, Robin. The Red Lamp of Incest. Nova York: E. P. Dutton, 1980.

GREENBERG, Maurice; LITTLEWOOD, Roland. Post-adoption incest and phenotypic matching: experience, personal meanings, and biosocial implications. British Journal of Medical Psychology, v. 68, p. 29-44, 1995.

HAVLICEK, Jan., \& ROBERTS, S. Craig. MHC-correlated mate choice in humans: A review. Psychoneuroendocrinology, v. 34, p.497-512, 2009.

HELGASON, Agnar; PÁLSSON, Snæbjörn; GUÓBJARTSSON, Daníel F; KRISTJÁNSSON, Pórður; STEFÁNSSON, Kári. An association between the kinship and fertility of human couples. Science, v. 319, p. 813-816, 2008.

LEACH, Edmmund. The social anthropology of marriage and mating. In: REYNOLDS, V; KELLETT, J. 
30 | José Francisco Carminatti Wenceslau e André Strauss

(Orgs.). Mating and Marriage. Oxford: Oxford University Press, 1991. p. 91-110.

LÉVI-STRAUSS, Claude. As estruturas elementares do parentesco. Tradução de Mariano Ferreira. Petrópolis: Editora Vozes, [1949] 1982.

. Apologue des amibes. In: JAMARD, Jean-Luc; TERRAY, Emmanuel; XANTHAKOU, Margaritha. (Orgs.). En substances: textes pour Françoise Héritier. Paris: Fayard, 2000. p. 493-496.

KANT, Immanuel. Speculative Beginning of Human History. In: Perpetual Peace and Other Essays. Tradução de Ted Humphrey. Indianapolis: Hackett Publishing Company, 1983.

McCARTY, Loretta M. Mother-child incest: Characteristics of the offender. Child Welfare, v. 65, p. 447-458, 1986.

MIDDLETON, Russell. Brother-sister and fatherdaughter marriage in Ancient Egypt. American Sociological Review, v. 27, p. 603-611, 1962.

PACKER, Craig; COLLINS, D. A; SINDIMWO, A; GOODALL, Jane. Reproductive constraints on aggressive competition in female baboons. Nature, v. 373, p. 60-63, 1995.

PHELAN, Patricia. Incest and its meaning: the perspective of fathers and daughters. Child Abuse \& Neglect, v. 19, n. 1, p. 7-24, 1995.

PUSEY, Anne. Inbreeding avoidance in chimpanzees. Animal Behaviour, v. 28, n. 2, p. 543-552, 1980.

PUSEY, Anne; WOLF, Marisa. Inbreeding avoidance in animals. Trends in Ecology and Evolution, v. 11, n. 5, p. 201-106, 1996.

Inbreeding Avoidance in Primates. In:

(Orgs.). Inbreeding, Incest and the Incest Taboo; the state of knowledge at the turn of the century. Stanford: Stanford University Press, 2005. p. 61-75.

RODSETH, L; WRANGHAM, R. W; HARRIGAN, A. M; e SMUTS, B. B. The human community as a primitive society. Current Anthropology, v. 32, p. 221-254, 1991.
SCHEIDEL, Walter. Ancient Egyptian Sibling Marriage and the Westermarck Effect. In: (Orgs.). Inbreeding, Incest and the Incest Taboo; the state of knowledge at the turn of the century. Stanford: Stanford University Press, 2005. p. 93-108.

SHEPHER, Joseph. Mate selection among second generation kibbutz adolescents and adults: Incest avoidance and negative imprinting. Archives of Sexual Behavior, v. 1, n. 4, p. 293-307, 1971.

SMITH, Adam. The Theory of Moral Sentiments. Oxford: Oxford University Press, 1976.

STRIER, Karen B. Mate preference of wild muriqui monkeys (Brachyteles arachnoides): reproductive and social correlates. Folia Primatologica, v. 68, p. 120-133, 1997.

SYMINGTON, M. McFarland. Sex ratio and maternal rank in wild spider monkey: When daughter disperse. Behavioral Ecology and Sociobiology, v. 20, p. 421-425, 1987.

VERDE, Filipe. Natureza, Incesto e Cultura: critica da teoria estrutural do incesto, da aliança e da reciprocidade. Dissertação (Mestrado) - Lisboa, 1994. Disponível em: <http://repositorio.iscte.pt/bitstream/10071/2339/1/dissertacao_filipeverde.pdf>. Acesso em: 12 jul. 2012.

YAMAZAKI, K; BEAUCHAMP, G. K; KUPNIEWSKI, K; BARD, J; THOMAS, L; e BOYSE, E. A., Familial Imprinting Determines H-2 Selective Mating Preferences. Science, v. 240, p. 1331-1332, 1988.

WEINBERG, S. Kirson. Incest Behavior. Nova York: Citadel, 1955.

WESTERMARK, Edward. The History of Human Marriage (Vol. 2). London, 1922.

WOLF, Arthur P. Explaining the Westermarck Effect, or, What Did Natural Selection Select For? In: (Orgs.). Inbreeding, Incest and the Incest Taboo; the state of knowledge at the turn of the century. Stanford: Stanford University Press, 2005. p. 76-92.

autores José Francisco Carminatti Wenceslau

Graduando em Ciências Biológicas / UNESP

André Strauss

Doutorando em Evolução Humana / Instituto Max Planck de

Antropologia Evolutiva

Recebido em 02/03/2012

Aceito para publicação em 01/10/2012

cadernos de campo, São Paulo, n. 21, p. 13-30, 2012 